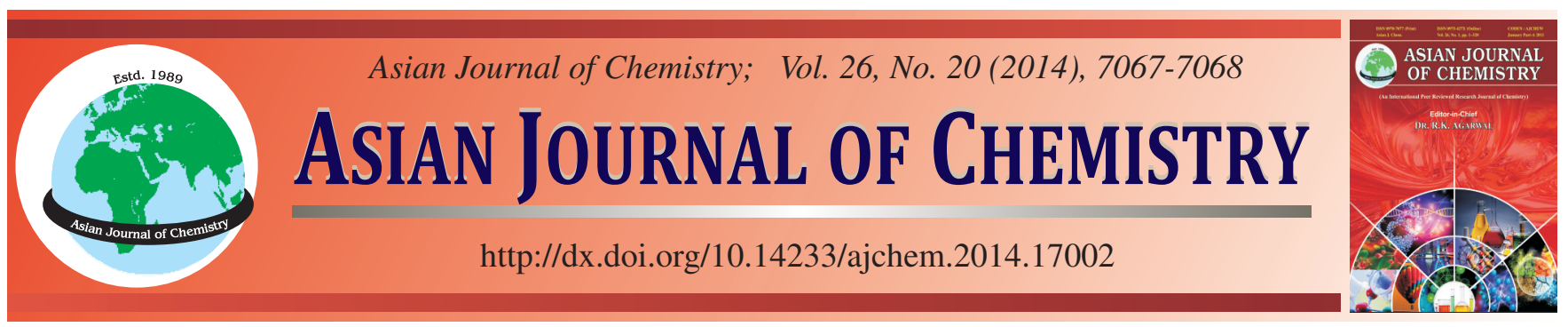

NOTE

\title{
Investigation of Antibacterial Activity of Alanine and Phenylalanine Derived Weinreb Amides Against Different Bacterial Strains
}

Zulfiqar Ali ${ }^{1, *}$, Syeda Rubina Gilani ${ }^{1}$, Farkhanda Jabeen $^{2}$, Habib Hussain $^{1}$, Hajira Rehman $^{3}$ and Imdad Hussain $^{1}$

${ }^{1}$ Department of Chemistry, University of Engineering and Technology, Lahore, Pakistan

${ }^{2}$ Department of Botany, University of Punjab, Lahore, Pakistan

${ }^{3}$ Department of Chemistry, University of Punjab, Lahore, Pakistan

*Corresponding author: Tel: +92 3214947884, E-mail: zulfi_ali_4@yahoo.com

Received: 7 January 2014;

Accepted: 22 April 2014;

Published online: 25 September 2014;

AJC-16068

\begin{abstract}
Weinreb amides derived from alanine and phenylalanine were tested against different bacterial strains. Antibacterial activity of weinreb amides were tested on 5 different strains i.e., E. coli, Pseudomonas aeruginosa, Staphylococcus aureus, Bacillus subtilis and Methicillinresistant Staphylococcus aureus. The antibacterial activity was evaluated using the Agar ditch method. The Weinreb amides 3, 4 and 5 exhibited good activity against E. coli, Pseudomonas aeruginosa and showed poor results against Staphylococcus aureus, Bacillus subtilis and Methicillin-resistant Staphylococcus aureus. The minimum inhibition concentrations of tested compounds were checked against each bacterial strain and results were recorded.
\end{abstract}

Keywords: Weinreb amides, Antibacterial activity, Minimum inhibition concentrations.

Antibacterial agents inhibit the bacterial growth or distinguish bacteria ${ }^{1}$. $N$-Methoxy- $N$-methylamides now popularly called Weinreb amides after their discoverer ${ }^{2}$ have lot of antibacterial activities against various pathogens. This functional group has become valuable synthetic intermediates in organic synthesis ${ }^{3}$. Weinreb amide is frequently used to synthesize $N$ protected amino acids, silyl ethers, $\alpha-\beta$ unsaturation various lactones and lactams and phosphonate esters ${ }^{4,5}$.

$N$-Acetyl cysteine is one of the $N$-protected amino acid. It has many medicinal applications i.e., used for the treatment of chest pain (unstable angina), for bile duct blockage in infants and an eye infection called keratoconjunctivitis.

$\beta$-Lactam antibiotics including penicillin derivatives i.e., monobactams and carbapenems ${ }^{6}$ used to alleviate bacterial infections. Initially, $\beta$-lactam antibiotics were found to be dynamic only against Gram-positive bacteria, but later on they proved their worth and utility against various Gram-negative organisms.

A lactone is a cyclic ester ${ }^{7}$ which is a condensation product of carboxylic acid group and alcoholic group within same molecule. Lactones are used to synthesize spirocyclic C-aryl glycosides that represent an antifungal antibiotics family isolated from a strain of Papularia sphaerosperna. They have shown strong antifungal activity against Candida albicans, Candida tropicalis, Pneumocystis carinii, among other microorganisms ${ }^{8}$.
In this study some new Weinreb amides synthesized by protecting $-\mathrm{NH}_{2}$ group of alanine and phenyl alanine with tosyl group (-OTs) and -dpp group (diphenyl phosphonic chloride) were tested against different gram positive and gram negative bacteria. Synthesized Weinreb amides proved their antibacterial activity by inhibiting the growth of these bacterial strains.

Tryptone (fluka), yeast extract, sodium chloride, bacteriological agar, DMF of analytical grade were purchased from sigma Aldrich. All chemicals were pure enough and used without further purification.

Microorganisms: All bacterial strains including gram negative bacteria i.e., E. coli, P. aeruginosa and Gram positive bacteria i.e., S. aureus, B. subtilis and Methicillin-resistant Staphylococcus aureus were obtained from the local collection at the Department of microbiology, University of Punjab Lahore, Pakistan.

Preparation of test compound: $2 \mathrm{mg}$ of the compound was dissolved in $1 \mathrm{~mL}$ of DMF in order to make the final concentration $0.2 \mathrm{mg} / 0.1 \mathrm{~mL}$. In all, 3 different concentrations of the compound were prepared $(0.2,0.02$ and $0.002 \mathrm{mg} / 0.1$ $\mathrm{mL}$ ) for microbiological assays.

L.B Broth preparation: L.B broth is prepared (without agar), shifted in five test tubes, each containing $5 \mathrm{~mL}$ broth and autoclaved. Inoculation of five bacterial strains were done in these test tubes and placed on shaker for $24 \mathrm{~h}$. 
Preparation of agar plates and microbiological assays: Severe sterilized and aseptic conditions were maintained and procedure was done in laminar airflow. Applying the agar plate diffusion technique 9 test organisms was grown in L.B nutrient agar medium. The composition of the medium was (g/L) tryptone $(1 \mathrm{~g})$, yeast extract $(0.5 \mathrm{~g})$, sodium chloride $(0.5 \mathrm{~g})$; agar (1.5-2 g) and water (100 mL). Every synthesized compound was tested according to pre mentioned concentration by dissolving in DMF, while DMF itself was used as control for comparison.

$\mathrm{N}$-Agar media was autoclaved and $25-30 \mathrm{~mL}$ of the media was added into the $9 \mathrm{~cm}$ diameter Petri-dish, allowed to solidify and then $1 \mathrm{~mL}$ bacterial suspension was transferred/plate incubated at $27^{\circ} \mathrm{C}$ for $24 \mathrm{~h}$. The wells were made in the plates with the help of autoclaved pasture pipette and then it was filled with the synthetic compound dissolved in DMF. The $100 \mu \mathrm{g} / \mathrm{mL}$ concentration was used and the activity of compound was determined by measuring the inhibition zone. The antibacterial activities of the synthetic compounds were determined against E. coli, Pseudomonas aeruginosa, Staphylococcus aureus, Bacillus subtilis and Methicillinresistant Staphylococcus aureus.

Pasteur and Joubert started the history of antimicrobials. More precisely antibiotics are those substances that are created by one microorganism and they can kill, or stop the growth of, another microorganism. Now-a-days the term antibiotic is used to refer any drug which is helpful to remove bacterial infection from the body. Antimicrobials comprise not just antibiotics but also synthetic compounds.

Three Weinreb amides 1, 2 and 3 as shown in Fig. 1 are synthetic antibiotics: The compounds 1-3 were utilized to study the in vitro growth inhibitory against different microbes. The organisms used to check the activity of compounds were E. coli, Pseudomonas aeruginosa, Staphylococcus aureus, Bacillus subtilis and Methicillin-resistant Staphylococcus aureus. The $100 \mu \mathrm{g} / \mathrm{mL}$ concentration was used of each compound against bacterial strains and inhibition zones were measured.<smiles>CON(C)C(=O)[C@H](C)N[AsH3]</smiles><smiles>[3H]N[C@@H](Cc1ccccc1)C(=O)N(C)OC</smiles>
weinreb amide of tosyl alanine (1) we inreb amide of tosyl phenylalanine (2)<smiles>CON(C)C(=O)[C@H](C)NC(=O)O[Na]</smiles>

weinreb amide of diphenyl p-ho sphinyl alanine (3)

Fig. 1. Weinreb amides with different $N$-protecting groups

According to the results (Table-1), all the compounds shown antimicrobial activities against any one of the selected bacterial strain.

\begin{tabular}{ccccccc}
\hline \multicolumn{7}{c}{ TABLE-1 } \\
\multicolumn{7}{c}{ ANTIBACTERIAL ACTIVITY OF COMPOUNDS } \\
\hline Comp. & E. coli & P. aeruginosa & S. typhi & S. aureus & B. subtilis & MRSA \\
\hline 1 & 80 & - & 45 & - & - & - \\
2 & 110 & 20 & 37 & - & 50 & - \\
3 & 110 & 15 & - & 95 & - & 40 \\
\hline
\end{tabular}

Note: Mean inhibition zones are measured in $\mathrm{mm}$

It is clear from above results that all the three synthesized compounds 1-3 showed varying degree of inhibition against the tested microorganisms. The minimum inhibition concentrations (MIC) of these three synthesized compounds against each bacterial strain are given in Table-2.

\begin{tabular}{ccccccc}
\multicolumn{7}{c}{ TABLE-2 } \\
MIC OF SYNTHESIZED COMPOUNDS \\
AGAINST DIFFERENT BACTERIAL STRAINS \\
\hline Comp. & E. coli & P. aeruginosa & S. typhi & S. aureus & B. subtilis & MRSA \\
\hline 1 & $30 \mu \mathrm{g}$ & - & $40 \mu \mathrm{g}$ & - & - & - \\
2 & $20 \mu \mathrm{g}$ & $20 \mu \mathrm{g}$ & $20 \mu \mathrm{g}$ & - & $30 \mu \mathrm{g}$ & - \\
3 & $10 \mu \mathrm{g}$ & $10 \mu \mathrm{g}$ & - & $30 \mu \mathrm{g}$ & - & $20 \mu \mathrm{g}$ \\
\hline
\end{tabular}

Note: MIC values are $\mu \mathrm{g} / \mathrm{mL}$ of the compound

It can be seen in Table- 2 that all the three compounds are not equally active against all bacterial strains but all are active against $E$. coli. Among all compound $\mathbf{3}$ was found to be more active against $E$. coli. Compounds $\mathbf{1}$ and $\mathbf{2}$ showed less or negligible activity aginst $S$. aureus and MRSA but compound 3 inhibited the growth of these bacterial strains.

\section{Conclusion}

All the three compounds $\mathbf{1}, \mathbf{2}$ and $\mathbf{3}$ showed activity against above selected human pathogens. The MIC values of these synthesized compounds in Table- 2 proved that compound $\mathbf{3}$ (Weinreb amide diphenylphosphinyl alanine) was found to be more active and effective against bacterial strains than compounds $\mathbf{1}$ and $\mathbf{2}$.

\section{ACKNOWLEDGEMENTS}

The authors are grateful to Botany Department University of Punjab, Lahore Pakistan for providing the lab facilities and guidance during this study. Thanks are also due to Higher Education Commission of Pakistan and Department of Chemistry, University of Engineering and Technology, Lahore Pakistan for providing research funds and lab reagents \& chemicals.

\section{REFERENCES}

1. Dorlands Medical Dictionary: Antibiotic, Archived from the Original on 2010-11-17. Retrieved 2010-10-29.

2. S. Nahm and S.M. Weinreb, Tetrahedron Lett., 22, 3815 (1981).

3. M.P. Sibi, Org. Prep. Proced. Int., 25, 15 (1993); M. Mentzel and H.M.R. Hoffmann, J. Prakt. Chem., 339, 517 (1997); J. Singh, N. Satyamurthi and I.S. Aidhen, J. Prakt. Chem., 342, 340 (2000).

4. J. Singh, N. Satyamurthi and I.S. Aidhen, J. Prakt. Chem., 342, 340 (2000).

5. M. Mentzel and H.M.R. Hoffmann, J. Prakt. Chem., 339, 517 (1997).

6. K.B. Holten and E.M. Onusko, Am. Fam. Phys., 62, 611 (2000).

7. M.B. Smith and J. March, March's Advanced Organic Chemistry: Reactions, Mechanisms and Structure, Wiley-Interscience, edn. 5 (2001).

8. S.E. Denmark, C.S. Regens and T.J. Kobayashi, J. Am. Chem. Soc., 129, 2774 (2007).

9. S.A. Waksman and H.C. Reilly, Ind. Eng. Chem. Anal. Ed., 17, 556 (1945). 